\title{
Clinical Analysis of Micafungin Treatment in Children with Candida Infection: A Single Center Experiment
}

\author{
Kandida Enfeksiyonu Olan Çocuklarda Mikafungin Tedavisinin Klinik Analizi: \\ Tek Merkez Deneyimi
}

\author{
Ayşe Şahin'(iD), Nazan Dalgıç'(ID), Ayşe Barış(ID), Banu Özata Abanoz'(ID) \\ ${ }^{1}$ Clinic of Pediatric Infectious Diseases, Sisli Hamidiye Etfal Training and Research Hospital, Istanbul, Turkey \\ ${ }^{2}$ Clinical Microbiology Laboratory, Sisli Hamidiye Etfal Training and Research Hospital, Istanbul, Turkey
}

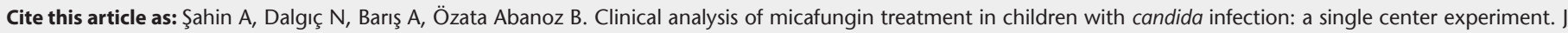
Pediatr Inf 2020;14(4):e181-e187.
\end{abstract}

\begin{abstract}
Objective: For the treatment of invasive candidiasis (IC) which is confirmed or suspected in adults, echinocandins are usually recommended. In children; however, very little is known about using echinocandins for IC management. Micafungin (MCFG) is approved for both treatment and prevention (prophylaxis) of invasive Candida infections. In this study, pediatric patients diagnosed with Candida infection and treated with MCFG were evaluated retrospectively. Clinical characteristics of the patients and the results of MCFG treatment were discussed in light of the literature.
\end{abstract}

Material and Methods: The study included 10 pediatric patients aged between 28 days and 16 years. They were diagnosed with Candida infection between January 01, 2017 and January 01, 2019, and were treated with MCFG. The patients' microbiological and laboratory data, demographic and clinical characteristics, risk factors for IC, MCFG treatment characteristics and the side effects were recorded retrospectively from electronic records.

Results: The median age of the patients in the study was 22 months (range 1.5 to $178 \mathrm{mo}$ ). Candida species isolated from the patients were C. parapsilosis, C. orthopsilosis, C. tropicalis, C. albicans, C. kefyr and C. guilliermondii. The most common underlying disease was gastrointestinal anomaly and related problems. The most common risk factors included the use of broad-spectrum antibiotics, total parenteral nutrition, mechanical ventilation, and central venous catheter. The median dose of MCFG was $2 \mathrm{mg} / \mathrm{kg}$ per day (d) and was applied to the patients for a
Öz

Giriş: Ekinokandinler yetişkinlerde olası ve kanıtlanmış invaziv kandidoz tedavisinde önerilmektedir. Bununla birlikte, çocuklarda invaziv kandidoz tedavisinde ekinokandinlerin kullanımı için çok az şey bilinmektedir. Mikafungin, invaziv kandida enfeksiyonlarının hem tedavisi hem de önlenmesi için onaylanmıştır. Bu çalışmada kandida enfeksiyonu tedavisinde mikafungin kullanılan çocuk hastalar retrospektif olarak irdelenmiştir. Hastaların klinik özellikleri ve mikafungin tedavisinin sonuçları literatür eşliğinde tartışılmıştır.

Gereç ve Yöntemler: Çalışmaya, 01 Ocak 2017-01 Ocak 2019 tarihleri arasında kandida enfeksiyonu tanısı alan ve mikafungin ile tedavi edilen, 28 gün ile 16 yaş arasında 10 çocuk hasta dahil edildi. Hastaların mikrobiyolojik ve laboratuvar verileri, demografik ve klinik özellikleri, invaziv kandidoz için risk faktörleri, mikafungin tedavi özellikleri ve yan etkiler geriye dönük olarak elektronik dosyalardan kaydedildi.

Bulgular: Çalışmaya katılan hastaların ortanca yaş 22 ay (1.5 ile 178 ay arasında) idi. Hastalardan izole edilen kandida türleri $C$. parapsilosis, $C$. orthopsilosis, C. tropicalis, C. albicans, C. kefyr, C. guilliermondii idi. En sık altta yatan hastalık gastrointestinal anomali ve ona bağlı gelişen sorunlardı. En sık görülen risk faktörleri; geniş spektrumlu antibiyotik kullanı$\mathrm{ml}$, total parenteral beslenme, mekanik ventilasyon, santral ven kateterinin bulunmasıydı. Mikafungin median dozu $2 \mathrm{mg} / \mathrm{kg} /$ gün idi. Hastalara en az 3 gün en fazla 23 gün kullanıldı. Mikafungin'e bağlı herhangi bir yan etki görülmedi. 
Şahin et al.

minimum of 3 days and a maximum of 23 days. There were no side effects observed.

Conclusion: In our limited case series of pediatric patients, MCFG was found effective in treating both proven and suspected invasive Candida infections and no adverse side effects were observed.

Keywords: Micafungin, children, invasive candidiasis

\section{Introduction}

Invasive diseases resulting from Candida (C) species is mostly linked with medical advancement and is mainly known as a primary cause of healthcare mortality and morbidity (1). Over 750.000 invasive candidiasis (IC) cases are reported yearly on a global scale (2). C. glabrata, C. parapsilosis, C. albicans, C. tropicalis and C. krusei are responsible for over $90 \%$ of invasive diseases (1).

Flucytosine, triazoles (e.g. fluconazole and voriconazole), amphotericin B are some antifungal agents used for the treatment of pediatric patients with IC. Nonetheless, these agents are faced with resistance and tolerability problems. Thus, studies are ongoing to find new antifungal agents to overcome these issues (3).

Echinocandins are a recent class of developed antifungal agents and consist of micafungin (MCFG), caspofungin and anidulafungin. They are semisynthetic cyclic lipopeptides and the mode of operation is inhibition of the synthesis of beta $(1,4)$-D-glucan in the cell wall of fungi, which is not found in mammalian cell walls(4).

The latest Infectious Disease Society of America (IDSA) guideline recommended echinocandins as introductory antifungal treatment for both neutropenic and non-neutropenic patients with IC and candidemia (1). Additionally, recent guidelines recommended by the European Society of Clinical Microbiology and Infectious Diseases (ESCMID) state echinocandins as the first-line treatment in IC $(5,6)$.

This is due to its advantages such as having a broad spectrum and effective antifungal property, minimal effect on the functions of the liver and kidneys, and not having an obstructive effect on other drugs (7).

In this study, the use of MCFG treatment in non-neonatal children diagnosed with Candida infection in a tertiary pediatric clinic was evaluated retrospectively. Demographic and clinical characteristics of the patients were reviewed in terms of side effects of the dose and duration of MCFG treatment in the follow-up and discussed with reference to the literature.

\section{Materials and Methods}

The study included 10 pediatric patients ( $>28$ days and $<16$ years of age) diagnosed with proven or suspected IC infection and treated with MCFG in a pediatric clinic between January 01,2017 , and January 01,2019 . Patients in the neonatal period and aged over 16 years were excluded.
Sonuç: Çocuk hastalardan oluşan sınırlı vaka serimizde MCFG, hem kanıtlanmış hen de olası invaziv kandida enfeksiyonlarının tedavisinde etkili bulunmuştur ve olumsuz bir yan etkiye rastlanmamıştır.

Anahtar Kelimeler: Mikafungin, çocuk, invaziv kandidoz

The study was approved by the local Committee of Ethics at the University of Health Sciences, Sisli Hamidiye Etfal Training and Research Hospital (\#1356).

According to the National Institute of Allergy and Infectious Diseases Mycoses Study Group (EORTC/MSG) and the European Organization for Research and Treatment of Cancer/ Cancer/Invasive Fungal Infections Cooperative Group consensus and the Mycosis Study Group Education and Research Consortium, proven IC is defined as Candida spp. recovery from an ordinarily sterile site accompanied with infectious signs and symptoms. Diagnosis of suspected IC is made according to the clinical judgement of investigators, taking into account risk factors for IC and laboratory abnormalities or clinical radiological compatible with the process of an infectious disease $(8,9)$. An absolute neutrophil count of $<500 \mu / L$ was defined as neutropenia (10).

The kind of feedback to treatment with MCFG has been documented with respect to the judgement of investigators. The complete or partial alleviation of IC signs/symptoms is considered as a favorable response, whereas consistent signs/ symptoms, advancement of the disease or death arising from any cause is considered as treatment failure, reflecting standard definitions (11).

The demographic structures, clinical, microbiological and laboratory data, underlying disease, diagnosis during hospitalization, surgical procedure, central vein catheter, mechanical ventilation, parenteral nutrition status of the patients were obtained from electronic file records. The date of diagnosis of Candida infection, time of starting micafungin treatment, its dose and duration of use, length of hospital stay, prior antifungal treatment and antibiotic treatment were recorded. Complete blood count, liver function tests, aspartate aminotransferase (AST), alanine aminotransferase (ALT), C-reactive protein (CRP), urea, creatinine were evaluated before, during and after micafungin treatment. Ocular examination, echocardiography for cardiac involvement, ultrasonography, and in cases where necessary, computerized tomography (CT) and magnetic resonance imaging (MRI) were performed to evaluate hepatosplenic candidiasis.

\section{Isolates}

Blood culture analyses were performed by BD Bactec FX (Becton Dickinson, Diagnostic Instrument System, Sparks, USA). Isolates were identified at the species level by matrix-as- 
sisted laser desorption ionization-time of flight mass spectrometry (MALDI-TOF MS) (Bruker Daltonics, Germany). The application of the in vitro susceptibility test (Sensititre Yeast One, TREK Diagnostic Systems, UK) and evaluation of the results were made according to the manufacturer's instructions. The interpretive species-specific clinical breakpoints (CBPs) and epidemiological cutoff values (ECV) were in accordance with the Clinical and Laboratory Standards Institute (CLSI) M60 and M59 guideline recommendations $(12,13)$.

\section{Statistical Analysis}

A descriptive analysis for demographic and baseline characteristics was performed. All statistical analyses were performed using SPSS software version 20.0 (SPSS, Armonk, NY, USA). Since the number of patients was under 30 , the median value was used in the descriptive statistics. Also, in case the data set has non-normal distribution and there are outliers, the median can be used instead of the mean.

\section{Results}

Median age of the patients was 22 months (range 1.5 to 178 months). Three of the patients were females (30\%). Demographic, clinical and microbiological characteristics and MCFG treatments of the patients are summarized in Table 1. Median length of hospital stay was 32 days (range 16-75 days) and the median duration of MCFG treatment was 14 days (range 3-23 days). Median time to culture negativity after starting micafungin treatment was 3.5 days. Two patients developed Klebsiella pneumonia growth in culture with Candida.

Among the facilitating risk factors for invasive fungal infection, the most common was the history of broad-spectrum antibiotic use followed by total parenteral nutrition (TPN) taking, long-term hospital stay in intensive care, presence of central venous catheter, monitoring in mechanical ventilation, and presence of neutropenia (Table 2). Broad spectrum antibiotics used before the development of Candida infection in patients were meropenem $(n=6)$, vancomycin $(n=3)$, piperacillin-tazobactam $(n=3)$, amikacin $(n=2)$ ceftazidime $(n=1)$ respectively.

C. tropicalis was the most frequently isolated Candida species. Other Candida species included C. orthopsilosis, C. parapsilosis, C. albicans, C. guilliermondii and C. kefyr. The Candida species isolated from the patients, their antifungal susceptibility and MIC values are given in Table 3 . Seven patients were diagnosed with proven and three with suspected IC infection.

The first case of suspected IC infection (patient no. 3) was a 14-y-old patient with complaints of fever, sores in the mouth, pain during eating and swallowing, and inability to eat. The patient had white plaques on the buccal mucosa, palate, tongue and oropharynx. Laboratory examination results obtained included white blood cell $26.200 / \mathrm{mm}^{3}$, platelet count $485,000 / \mathrm{mm}^{3}$ (polymorphonuclear leukocytes; 20.900/ $\mathrm{mm}^{3}$, lymphocyte; $1230 / \mathrm{mm}^{3}$, eosinophil $2860 / \mathrm{mm}^{3}$, anisocytosis, hypochromia and dense band formation in peripheral blood smear), CRP $147 \mathrm{mg} / \mathrm{dL}$ (normal $<0.5 \mathrm{mg} / \mathrm{dL}$ ) and total $\mathrm{lgE}$ $4570 \mathrm{IU} / \mathrm{ml}$. (reference range $0-52 \mathrm{lU} / \mathrm{ml}$ ) The patient was evaluated as having oropharyngeal and esophageal candidiasis and was diagnosed with hyperimmunoglobulin E syndrome (Hyper lgE syndrome) in the follow-up. After not responding to three $\mathrm{d}$ of fluconazole treatment, MCFG treatment was started and clinical response was obtained within $72 \mathrm{~h}$. The treatment was completed in 14 days and the patient was discharged.

The second case (patient no.9) was a 3.5-mo-old girl with long-term neonatal intensive care hospitalization who received broad-spectrum antibiotic treatment for recurrent Gram-negative sepsis. Duo to clinical deterioration, fever, thrombocytopenia, and elevated CRP under broad-spectrum antibiotic, $2 \mathrm{mg} / \mathrm{kg}$ per day MCFG treatment was started empirically, considering suspicious Candida infection. There was no culture growth in the patient whose general condition improved after the treatment. The antifungal treatment was completed after 14 days.

The third case (patient no.5) was a 13-y-old male and was hospitalized for febrile neutropenia (absolute neutrophil count $450 / \mu / L$ ) while receiving chemotherapy with an acute myeloid leukemia. On continuation of fever on the $5^{\text {th }}$ $\mathrm{d}$ of broad-spectrum antibiotic treatment, two fungal nodules were detected in the thorax tomography. Amphotericin B was added to the treatment. In the treatment, the patient whose fever continued was sent for abdominal MRI and it showed multiple microabcesses in the liver and spleen. Caspofungin was then added to the treatment. On the $8^{\text {th }}$ day of treatment, no clinical response was obtained and the treatment was changed to $2 \mathrm{mg} / \mathrm{kg}$ of MCFG per day. On the $4^{\text {th }}$ day of this treatment, the patient's fever reduced, and clinical response was obtained. MCFG treatment was completed in 23 days and the patient was discharged under oral antifungal prophylaxis.

When the patients were evaluated in terms of their underlying diseases, congenital anomalies were the most common causes including gastrointestinal tract in five patients and CNS pathology in two patients. Two patients had leukemia and one patient was diagnosed with hyper IgE syndrome at the follow-up.

Seven patients had received different antifungal agents (fluconazole to five patients and amphotericin-B to two patients) before MCFG. Due to transaminase elevation under fluconazole treatment in one patient, the treatment was changed to MCFG. In the other six patients, MCFG treatment was started because of no clinical and laboratory response. None of the patients developed side effects with no condition requiring discontinuation of the drug during the MCFG treatment. 


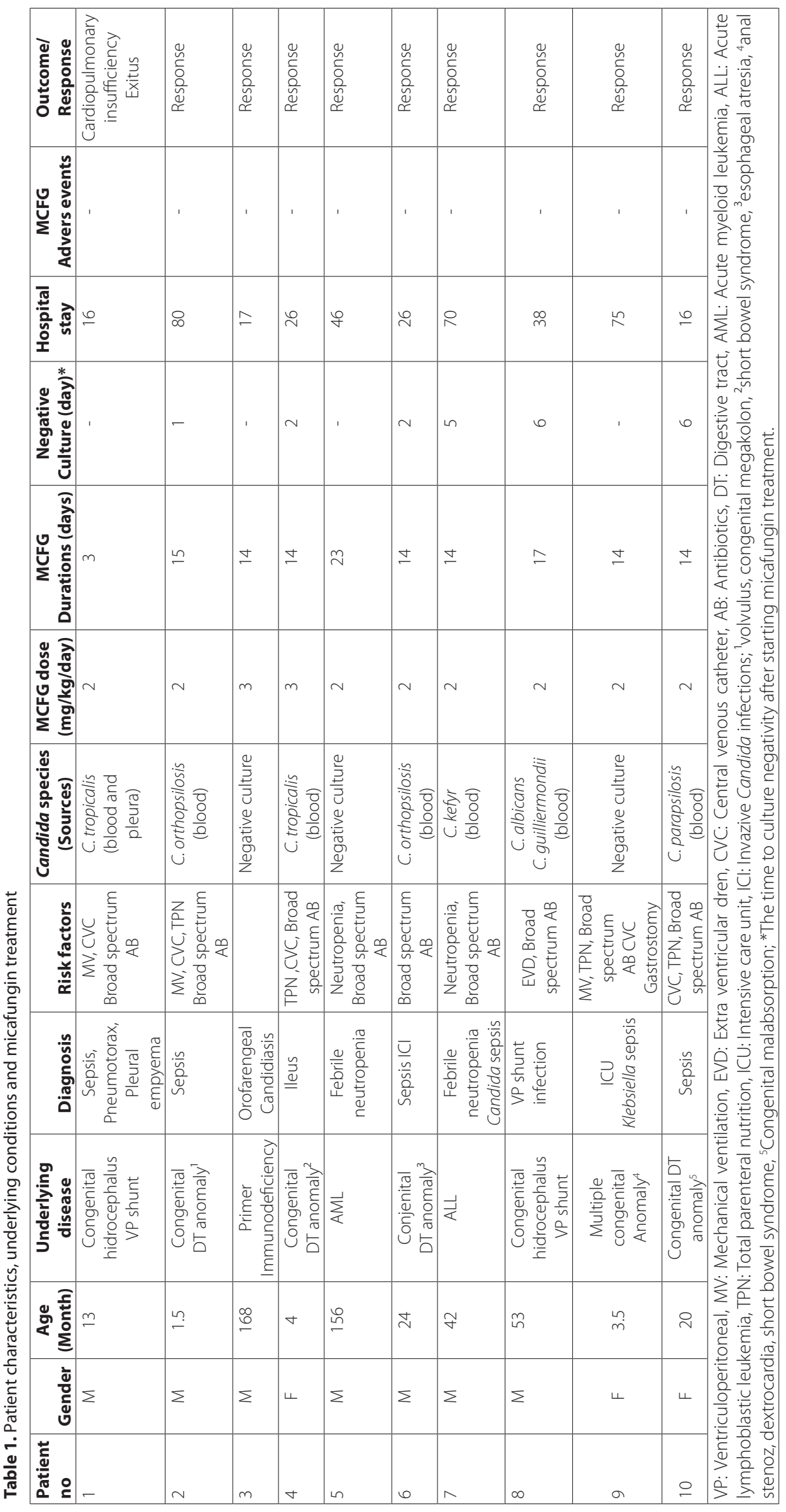


Table 2. Risk factors

\begin{tabular}{|l|c|}
\hline Risk factors & Patients (n: 10) \\
\hline Broad-spectrum antibiotic & 10 \\
\hline Total parenteral nutrition & 6 \\
\hline Intensive care unit & 5 \\
\hline Central venous catheter & 4 \\
\hline Mechanical ventilation & 3 \\
\hline Neutropenia & 2 \\
\hline
\end{tabular}

Table 3. Antifungal susceptibility profiles of the Candida species

\begin{tabular}{|c|c|c|c|c|c|c|c|c|c|c|}
\hline \multirow[b]{2}{*}{ Patients } & \multirow[b]{2}{*}{ Candida species } & \multicolumn{9}{|c|}{ Minimal inhibitory concentrations of antifungals $(\mu \mathrm{g} / \mathrm{ml})$ (Interpretive Categories) } \\
\hline & & $5 \mathrm{FC}$ & ITC & POS & VRC & AFG & AMB & CAS & MFG & $5 \mathrm{FC}$ \\
\hline \multirow[t]{2}{*}{1} & C. tropicalis & $1(\mathrm{~S})$ & $0.25(\mathrm{WT})$ & $0.25(\mathrm{WT})$ & $0.12(S)$ & $0.015(S)$ & $1(\mathrm{WT})$ & $0.015(S)$ & $0.015(S)$ & $<0.06$ \\
\hline & C. tropicalis & $1(\mathrm{~S})$ & 0.12 (WT) & 0.06 (WT) & $0.12(S)$ & $0.03(\mathrm{~S})$ & $1(\mathrm{WT})$ & $0.03(\mathrm{~S})$ & $0.015(S)$ & 1 \\
\hline 2 & C. orthopsilosis & $1(\mathrm{~S})$ & 0.12 & 0.06 (WT) & $0.06(S)$ & $0.5(\mathrm{~S})$ & 0.5 (WT) & $0.12(\mathrm{~S})$ & $0.25(\mathrm{~S})$ & 0.12 \\
\hline 3 & C. tropicalis & $1(\mathrm{~S})$ & 0.12 (WT) & 0.06 (WT) & $0.12(S)$ & $0.03(S)$ & 0.5 (WT) & $0.03(S)$ & $0.03(\mathrm{~S})$ & 0.25 \\
\hline 4 & C. orthopsilosis & $1(\mathrm{~S})$ & 0.06 & 0.03 (WT) & $0.03(\mathrm{~S})$ & $2(S)$ & $1(\mathrm{WT})$ & $0.5(\mathrm{~S})$ & $1(S)$ & $<0.06$ \\
\hline 5 & C. kefyr & 1 & 0.06 & 0.06 & 0.03 & 0.5 & 2 & 0.25 & 1 & 0.25 \\
\hline \multirow[t]{2}{*}{6} & C. albicans & $0.25(\mathrm{~S})$ & 0.06 & 0.03 (WT) & $<0.008(\mathrm{~S})$ & $0.015(S)$ & 0.5 (WT) & $0.015(S)$ & $<0.008(\mathrm{~S})$ & 0.12 \\
\hline & C. guilliermondii & $2(\mathrm{WT})$ & 0.06 & 0.03 (WT) & 0.03 & $0.5(S)$ & 0.5 & $0.5(\mathrm{~S})$ & $0.25(\mathrm{~S})$ & $<0.06$ \\
\hline 7 & C.parapsilosis & $1(S)$ & 0.12 & 0.06 (WT) & $0.03(\mathrm{~S})$ & $2(S)$ & $1(\mathrm{WT})$ & $0.5(\mathrm{~S})$ & $2(S)$ & 0.25 \\
\hline
\end{tabular}

The patient with V-P shunt was admitted to the emergency room due to fever and respiratory distress. The patient was taken to the intensive care unit because of pneumonia, and there was $C$. tropicalis growth in the blood and pleural cultures. There was no growth in the CSF culture, shunt infection was not considered but the patient died on the $4^{\text {th }}$ day of MCFG treatment due to cardiopulmonary insufficiency.

\section{Discussion}

Candida species, the most prevalent cause of invasive fungal infections in children, are the third most common etiology of healthcare based bloodstream infections in Europe, Latin America and the USA (14). C. albicans still remains the most commonly isolated species in IC; however, the occurrence of non-albicans Candida (NAC) has risen in recent years $(10,15,16)$. In our study, C. tropicalis was isolated in three patients (33.3\%), C. orthopsislosis in two patients (22.2\%), C. parapsilosis in one patient (11.1\%), C. albicans in one patient (11.1\%), C. kefyr in one patient (11.1\%) and C. guilliermondii in one patient (11.1\%).

There are host-related factors that lead up to the development of Candida infection. In a study by Kishimoto et al., Candida infection has been detected in 11 of 13 patients with IFD. Congenital anomaly and malignancy have been found to be the most common host-related factors for underlying fungal infection (10). In our study, the most common underlying cause was congenital anomalies, which included anomalies of the related gastrointestinal tract (five out of ten patients) including anal atresia, esophageal atresia, congenital megacolon, and congenital anomalies related to CNS (two of ten patients).

Normal gastrointestinal barrier plays an important role in the prevention of candidiasis. Recent studies indicate that babies with underlying gastrointestinal system abnormalities are more prone to systemic Candida infection and that elimination of mucosal deterioration and normal gastrointestinal flora caused by surgical treatment of patients using antimicrobial therapy causes susceptibility to Candida infections $(17,18)$.

There are several risk factors for IC including the existence of central venous line, malignant disease, neutropenia, the usage of immunosuppressive drugs or broad spectrum antimicrobial agents, total parenteral nutrition, respiratory or cardiovascular diseases, congenital immunodeficiencies, (e.g., chronic granulomatous disease, Hyper IgE syndrome, recent surgery or intensive care unit admission and mechanical ventilation) $(19,20)$. 
Santaloya et al. have conducted a prospective study in a multicenter with 384 cases and reported the use of broad-spectrum antibiotic and CVC as the most common (over 70\%) risk factors in all age groups (21). In another study on pediatric patients with candidemia, the use of broad-spectrum antibiotics has been reported as the most common risk factor (22). In our patients, the most common risk factors for IC were the use of broad-spectrum antibiotic therapy, CVC use, long-term hospitalization and ICU stay, and TPN administration, similar to other studies.

Conventional treatments such as amphotericin B and fluconazole are effective in the treatment of Candida infections. However, weak tolerability of amphotericin B and emergence of fluconazole-resistant Candida species required the development of effective and safer alternatives (23).

With respect to other antifungal agents, echinocandins has major advantages such as effective fungicidal activity against Candida spp, including fluconazole-resistant $C$. krusei and C. glabrata, in addition to their relatively low tendency for hepatic toxicity or renal or serious inter drug interactions (24).

Potency of MCFG in IC pediatric patients has been investigated in a sub-study as part of an expected, double masked, random trial comparing MCFG with liposomal amphotericin $B$ as a first-line therapy of IC for at least of $14 \mathrm{~d}$. A sum total of 106 patients have been included as the intent-to-treat group. The respective treatment success recorded for $38 / 50$ patients treated with liposomal amphotericin B and 35/48 patients treated with micafungin were $76.0 \%$ and $72.9 \%$, respectively. Both treatments have shown good tolerance. In light of this, MCFG promises to be an effective and safe treatment for freshly diagnosed or refractory candidemia in children and adults, caused by both C. albicans and non-albicans species(24).

In a twenty-year surveillance study covering South America, Latin America, Europe and the Asia-Pacific region; 15308 invasive Candida isolates, obtained from 39 countries were investigated for micafungin sensitivity. In Europe, micafungin resistance was found in only C. albicans and C. glabrata species, which had resistance rates of $0.1 \%$ and $0.6 \%$, respectively. Micafungin MIC values were quite low in seven isolates included in our study and no resistant or non-wild type isolates were observed (25).

MCFG treatment dose: The recommended doses for the powdery form used in preparing intravenous solutions for patients weighing $40 \mathrm{~kg}$ or more and children older than 4 months but weighing below $40 \mathrm{~kg}$ are $50-200$ and $1-4 \mathrm{mg} / \mathrm{kg}$ per day, respectively. For children younger than 4 months, no loading dose is required (26). The dose of MCFG applied to our patients was between $2-3 \mathrm{mg} / \mathrm{kg}$ per day.
For children who are responsive to empiric antifungal therapy, there is no data that guides the duration of treatment. However, the duration of treatment should not differ much from the one documented for candidemia, which is usually for two weeks after registered clearance of Candida spp. from the bloodstream and resolution of all signs associated with candidemia. In different studies, the mean duration of MCFG treatment for IC was 14 days, with a minimum of 8 and a maximum of 4 weeks $(11,24)$.

The median duration of MCFG use in our patients was 14 days. The shortest period of use was 3 days and the longest period was 23 days.

A multicenter prospective observational study by Viscoli et al. on suspected and proven invasive candidiasis in 108 children and adult patients on a real-human population has shown that the percentage of people that discontinued therapy due to adverse events were only $4 \%$ (4/108). On the other hand, $67 \%$ of patients (70/104) recorded positive response at the end of treatment 90\% (97/108) was recorded as overall survival (11).

The meta-analysis research by Tsekoura et al. on the efficacy and safety of echinocandins in the treatment of IC in children has shown no significant difference between treatment success and incidence of adverse events. However, in the MCFG group, cases that required discontinuation of the drug were observed in fewer patients compared to amphotericin B (4).

Side effects of MCFG included fever, rash, phlebitis, nausea, vomiting, diarrhea, headache, hypokalemia, and impaired liver function tests. MCFG-related adverse reactions are minimal because 1.3-ß-D-glucan is specific to fungal cell walls and is not found in human cells (27).

In our patients, no side effects that would require discontinuation of the drug were observed during the treatment with MCFG. A 1-day-old patient diagnosed with congenital megacolon was operated on and upon the increase in liver enzymes on the 32nd day of fluconazole antifungal agents, fluconazole was discontinued and MCFG $5 \mathrm{mg} / \mathrm{kg}$ per day was started. The patient clinically responded well to MCFG treatment and had no growth in the control blood culture. ALT and GGT values returned to normal in the follow-up, and the patient was discharged after completing the treatment in 14 days.

\section{Conclusion}

In our patients including children, MCFG has been used as an effective and safe treatment option in the proven and suspected IC treatment. In the treatment of MCFG Candida infection, it can be considered as a promising treatment option in the pediatric age group, but further studies with larger patient series are needed on this subject. 
Ethics Committe Approval: The approval for this study was obtained from Health Science University Şişli Hamidiye Etfal Training and Research Hospital Clinical Research Ethics Committee (Decision no: 2552, Date: 01.10.2019).

Informed Consent: Patient consent was obtained.

Peer-review: Externally peer-reviewed.

Author Contributions: Concept - AŞ, ND; Design - AŞ; Supervision - AŞ, ND; Resource - AŞ, ND, AB; Data Collection and/or Processing - $A S ̧, A B, B O ̈ A ;$ Analysis and/or Interpretation - AŞ, ND, AB; Literature Search - AŞ; Writing - AŞ; Critical Review - AŞ, ND, AB, BÖA.

Conflict of Interest: Authors declared no conflict of interest.

Financial Disclosure: The authors declared that this study has received no financial support.

\section{References}

1. Pappas PG, Kauffman CA, Andes DR, Clancy CJ, Marr KA, Ostrosky-Zeichner $L$, et al. Clinical practice guideline for the management of candidiasis: 2016 update by the Infectious Diseases Society of America. Clin Infect Dis 2015;62:e1-e50. [CrossRef]

2. Vasileiou E, Apsemidou A, Vyzantiadis T-A, Tragiannidis A. Invasive candidiasis and candidemia in pediatric and neonatal patients: A review of current guidelines. Current medical mycology 2018;4:28. [CrossRef]

3. Scott LJ. Micafungin: a review in the prophylaxis and treatment of invasive Candida infections in paediatric patients. Pediatric Drugs 2017;19:81-90. [CrossRef]

4. Tsekoura M, loannidou M, Pana ZD, Haidich AB, Antachopoulos C, Iosifidis $E$, et al. Efficacy and safety of echinocandins for the treatment of invasive Candidiasis in children: a meta-analysis. The Pediatric Infect Dis J 2019;38:42-9. [CrossRef]

5. Tissot F, Agrawal S, Pagano L, Petrikkos G, Groll AH, Skiada A, et al. ECIL6 guidelines for the treatment of invasive candidiasis, aspergillosis and mucormycosis in leukemia and hematopoietic stem cell transplant patients. Haematologica 2017;102:433-44. [CrossRef]

6. Hope W, Castagnola E, Groll A, Roilides E, Akova M, Arendrup M, et al. Guideline for the diagnosis and management of Candida diseases 2012: prevention and management of invasive infections in neonates and children caused by Candida spp. Clin Microbiol Infect 2012:38-52. [CrossRef]

7. Funaki T, Miyairi I. Breakthrough candidemia in children on micafungin. Pediatric Infect Dis J 2018;37:1258-60. [CrossRef]

8. De Pauw B, Walsh TJ, Donnelly JP, Stevens DA, Edwards JE, Calandra T, et al. Revised definitions of invasive fungal disease from the European organization for research and treatment of cancer/invasive fungal infections cooperative group and the national institute of allergy and infectious diseases mycoses study group (EORTC/MSG) consensus group. Clin Infect Dis 2008;46:1813-21. [CrossRef]

9. Donnelly JP, Chen SC, Kauffman CA, Steinbach WJ, Baddley JW, Verweij $P E$, et al. Revision and update of the consensus definitions of invasive fungal disease from the European Organization for Research and Treatment of Cancer and the Mycoses Study Group Education and Research Consortium. Clin Infect Dis 2020 12;71:1367-76. [CrossRef]

10. Kishimoto K, Kasai M, Kawamura N, Ito Y, Yoshida M, Hasegawa D, et al. Clinical features in proven and probable invasive fungal disease in children and adolescents at a pediatric referral center: a 5-year experience. World J Pediatr 2019;1-6. [CrossRef]
11. Viscoli C, Bassetti M, Castagnola E, Cesaro S, Menichetti F, Ratto S, et al. Micafungin for the treatment of proven and suspected invasive candidiasis in children and adults: findings from a multicenter prospective observational study. BMC Infect Dis 2014;14:725. [CrossRef]

12. Wayne PA. Epidemiological cutoff values for antifungal susceptibility testing. CLSI supplement. $2^{\text {nd }}$ ed. Clinicaland Laboratory Standards Institute, 2018:M59. [CrossRef]

13. Wayne P. Performance standards for antifungal susceptibility testing of yeasts. CLSI supplement. CLSI supplement. $1^{\text {st }}$ ed. 2017, M60. [CrossRef]

14. Palazzi DL, Arrieta A, Castagnola E, Halasa N, Hubbard S, Brozovich AA, et al. Candida speciation, antifungal treatment and adverse events in pediatric invasive candidiasis: results from 441 infections in a prospective, multi-national study. Pediatric Infect Dis J 2014;33:1294-6. [CrossRef]

15. Chan S, Baley ED, Hossain J, Di Pentima MC. Candida species bloodstream infections in hospitalised children: A 10-year experience. J Paediatr Child Health 2015;51:857-61. [CrossRef]

16. Noni M, Stathi A, Vaki I, Velegraki A, Zachariadou L, Michos A. Changing epidemiology of invasive candidiasis in children during a 10-year period. Journal of Fungi 2019;5:19. [CrossRef]

17. Weichert S, Reinshagen K, Zahn K, Geginat G, Dietz A, Kilian AK, et al. Candidiasis caused by Candida kefyr in a neonate: case report. BMC Infect Dis 2012;12:1-4. [CrossRef]

18. Cugno C, Cesaro S. Epidemiology, risk factors and therapy of candidemia in pediatric hematological patients. Pediatr Rep 2012;4:e9. [CrossRef]

19. Emiroglu M. Micafungin use in children. Expert Rev Anti Infect Ther 2011;9:821-34. [CrossRef]

20. Marodi L, Johnston RB. Invasive Candida species disease in infants and children: occurrence, risk factors, management, and innate host defense mechanisms. Curr Opin Pediatr 2007; 19:693-7. [CrossRef]

21. Santolaya ME, Thompson L, Benadof D, Tapia C, Legarraga P, Cortés $C$, et al. A prospective, multi-center study of Candida bloodstream infections in Chile. PLoS One 2019;14:e0212924. [CrossRef]

22. Blyth CC, Chen SC, Slavin MA, Serena C, Nguyen Q, Marriott D, et al. Not just little adults: candidemia epidemiology, molecular characterization, and antifungal susceptibility in neonatal and pediatric patients. Pediatrics 2009;123:1360-8. [CrossRef]

23. Benjamin DK, Kaufman DA, Hope WW, Smith PB, Arrieta A, Manzoni P, et al. A phase 3 study of micafungin versus amphotericin $b$ deoxycholate in infants with invasive candidiasis. Pediatric Infect Dis J 2018;37:992. [CrossRef]

24. Queiroz-Telles F, Berezin E, Leverger G, Freire A, van der Vyver A, Chotpitayasunondh $T$, et al. Micafungin Invasive Candidiasis Study Group: Micafungin versus liposomal amphotericin B for pediatric patients with invasive candidiasis: substudy of a randomized double-blind trial. Pediatr Infect Dis J 2008;27:820-6. [CrossRef]

25. Pfaller MA, Diekema DJ, Turnidge JD, Castanheira M, Jones RN (Eds). Twenty years of the SENTRY antifungal surveillance program: results for Candida species from 1997-2016. Open forum infectious diseases; USA: Oxford University Press, 2019. [CrossRef]

26. Wasmann RE, Muilwijk EW, Burger DM, Verweij PE, Knibbe CA, Brüggemann RJ. Clinical pharmacokinetics and pharmacodynamics of micafungin. Clin Pharmacokinet 2018;57:267-86. [CrossRef]

27. Kaushik $A$, Kest $H$. The role of antifungals in pediatric critical care invasive fungal infections. Crit Care Res Pract 2018;2018:8469585. [CrossRef] 